\title{
AZ ÉRTÉKTEREMTÉS SZEREPE A SZOLGÁLTATÓ VÁLLALKOZÁSOK VERSENYKÉPESSÉGÉBEN
}

A fogyasztói érték népszerú fogalma számos elméleti alátámasztást nyert a versenyképesség elméleti, mikroszintú megközelítéseiben. Kifejezetten fontos aspektusát képezi a szolgáltató szervezetek sikerességének. Számos fogyasztóiérték-kutatás hangsúlyozza, hogy az érték napjainkban leginkább a fogyasztói élményekben ragadható meg. Jelen tanulmányban ezért a szerzố célja a fogyasztói érték, az élmény és a szolgáltatóvállalkozások versenyképessége közötti elméleti összefüggés bemutatása. ${ }^{1}$

\section{Kulcsszavak: fogyasztói érték, versenyképesség, élmény}

A vállalati versenyképesség növelése hazai és nemzetközi szinten is prioritást élvez. A szolgáltatóipar, így többek között a turizmusfejlesztési stratégiák (MTH, 2005; NGM, 2011) fókuszában is a versenyképesség és az életminốség javítása áll. Ezek a fejlesztési irányok értékközpontú és piaci kereslet által vezérelt meghatározását irányozzák elő, melyek kiindulópontja, hogy a szolgáltatók által nyújtott értékek, illetve a fogyasztók motivációi elsősorban az élményekból épülnek fel.

Jelen tanulmány célja a versenyképesség és értékteremtés keresletoldali jelentőségének vizsgálata. A következố logikai ív mentén haladok: ismertetem a versenyképesség-elméletek megközelítéseit és választásának indoklását, majd az értékteremtés és a versenyképesség kapcsolatát mutatom be, a vizsgálati fókuszt a vevôi/fogyasztói érték ${ }^{2}$ összetevôire és jelentôségére helyezve, végül a téma feldolgozását a fogyasztói érték és az élménykategória összefüggéseinek elemzésével zárom.

\section{A versenyképesség fogalma és összetevôi}

\section{Versenyképesség-megközelítések}

A versenyképesség-kutatás és -mérés napjainkban igen elterjedt és népszerú. Fogalmi lehatárolása nem lehet egységes, hiszen a versenyképesség relatív, és többféle nézőpontból értelmezhetô. A versenyképesség kutatása folyamatos, definíciói sok vitát eredményez- nek. Egy átfogó és mindenki által elismert definícióalkotásra törekedve Chikán (2006: p. 42.) úgy érvelt, hogy „a versenyben való helytállás a túlélés feltétele a gazdaság valamennyi szintjén. Ebben az általános megfogalmazásban valószínúleg mindenki egyetért."

Az egyes versenyképesség-megközelítések közül az alábbiakat emelem ki (vö. Sziva, 2010):

- Ex post/ex ante megközelítés

Az ex post versenyképesség az eddig elért eredményekre, azaz a múltbeli teljesítmény mutatószámaira, a versenyképesség javulására vagy romlására vonatkozik. Az ex post megközelítés lehetôvé teszi a vizsgálati egységek versenyképességének összehasonlítását, egyrészt a múltbeli eseményekhez képest, másrészt a versenytársakhoz képest. Az ex ante oldal a versenyképességet meghatározó tényezókre vonatkozik: kiterjed a versenyelőnyt nyújtó feltételekre, az üzleti környezet adottságaira. Az ex ante oldal vizsgálata a vállalatok és a gazdaságirányítás szempontjából kiemelendô, mivel arra a kérdésre keresi a választ, hogy milyen tényezókre szükséges hatni a versenyképesség növelése érdekében (Török, 2005; Lengyel, 2000; Némethné, 2010).

\section{- Kínálati/keresleti oldali megközelítés}

Török (1996) hangsúlyt helyez a versenyben való helytállás két oldalára: a termelés hatékonyságára és a keresletnek való megfelelésre. Ilyen módon, a kínálati oldalon megjelenô versenyképességet a termelés 
hatékonyságában, míg a keresletoldalit a világpiaci kereslet követelményeinek való megfelelésben látja. A két dimenzióban együttesen elért siker a versenyképesség alapja, ugyanakkor az összehangolást a mérhetôség problémája akadályozza, mivel a kínálati oldalon a költségelónyökben, míg a keresleti oldalon a teljesítményben mérhetố a versenyképesség (Török, 1996; Francis, 1989, 1992 in: Czakó, 2000: p. 24.).

- Értelmezési szintek szerinti megközelítés

A versenyképesség hagyományosan a gazdaság négy szintjére - nemzeti, ágazati, vállalati és termék - vonatkozhat (Chikán, 2006; Majoros, 1997), melyek közül kiemelt figyelmet kap a makrogazdasági (nemzetgazdasági) és a mikrogazdasági (vállalkozási) szint az elméleti megközelítések sorában.

- Közgazdaságtani/gazdálkodástani megközelítés A versenyképesség elméleti megközelítései közül kiemelendő a közgazdaságtani és a gazdálkodástani irány. A versenyképesség közgazdaságtani megközelítésének fókuszában elsődlegesen a nemzetgazdaságok teljesítménye és külgazdasági kapcsolatai állnak. $\mathrm{Az}$ e területen végzett „,(..) versenyképességi kutatások egyik legfontosabb gyökerét és inspirációját a makroökonómia és különösen a nemzetközi gazdaságtan jelenti” (Czakó, 2000: p. 26.). A közgazdaságtani megközelítés makroszinten vizsgálja a versenyképességet, míg a gazdálkodástani megközelítés a vállalatok oldaláról közelít. A makrogazdasági versenyképesség vizsgálatakor a gazdálkodástani irány legfontosabb kiindulópontja az, hogy egy nemzetgazdaság akkor sikeres a nemzetközi versenyben, ha vállalatai sikeresek. Ebból a szempontból a gazdálkodástani versenyképesség-kutatások az ex ante tényezókre helyezik a hangsúlyt, választ keresve arra a kérdésre, hogy milyen versenykörnyezeti feltételek biztosítása szükséges annak érdekében, hogy a vállalatok versenyképesen múködjenek, és ezáltal maga a nemzetgazdaság is versenyképes legyen. A versenyképesség gazdálkodástani háttérelméletének kiemelkedő sarokpontját Michael Porter munkássága adja. Porter (1990) szerint a megváltozott gazdasági, kereskedelmi és pénzügyi kapcsolatrendszerben, a nemzetek összefonódása miatt a XX. században a tényezőellátottságon alapuló komparatív elônyök nem biztosítják egy ország jólétét, és a „helyileg megteremthető versenyelónyök", a kompetitív előnyök mellett érvel.

\section{Versenyképesség mikroszinten}

A vállalati versenyképesség definiálása szintén több szakirodalmi vitát váltott ki, a megközelítésmódok sokszínúsége ellenére a kutatói álláspontok megegyeznek abban, hogy:
- a vállalatok versenyképessége nem választható el az általuk elóállított termékek, szolgáltatások versenyképességétól, amelyet árjellegú és nem árjellegú tényezók egyaránt befolyásolnak,

- a vállalati versenyképességet számos tényezô együttes hatása alakítja, amelyeket nem célszerú egy adott pillanatban vizsgálni, hanem mindig $d i$ namikusan, a változások tendenciáit figyelembe véve kell értékelni (Némethné, 2010: p. 181.).

A termékek (szolgáltatások) versenyképessége kifejeződhet abban, hogy az áru:

- ára a versenytársakénál alacsonyabb,

- minósége, múszaki színvonala meghaladja a konkurens árukét,

- a kapcsolódó szolgáltatások a versenytársakénál elónyösebbek a vevốk számára.

Egy áru akkor tekinthetô versenyképesnek, ha a felsorolt három alternatíva közül legalább kettóvel rendelkezik (Botos, 1982 in: Némethné, 2010: p. 182.).

A termékhez közvetlenül kapcsolódó jellemzók határozzák meg elsôsorban a vállalatnak a piaci részesedés megtartására és növelésére való képességét, azonban a vállalati versenyképességnek ez csak az egyik öszszetevője. A vállalati versenyképesség értelmezésekor ezen túl a hatékonyságot, a stratégiaalkotást, eróforrásokat, vállalati képességeket, tudást, emberi tényezóket is indokolt figyelembe venni (Findrik - Szilárd, 2000; Szentes, 2005; Chikán, 2006).

A fenti megközelítés egyesíti a versenyképesség kereslet- és kínálatoldali tényezôit, melyekkel összhangban áll Chikán Attila (2006: p. 44.) felfogása. Eszerint „a vállalat kettós értékteremtố tevékenységet folytat: ugyanazon folyamatban kell megvalósítania a fogyasztói érték és a tulajdonosi érték létrehozatalát".

A tartós versenyelóny feltételeit egyes szerzók a vállalati erôforrásokhoz és alapvetô képességekhez rendelik (Grant, 1991; Barney, 1996; Prahalad - Hamel,1990), melyek közös elemeit képezi a nehéz másolhatóság, a tartósság, a vevői érték nyújtása és az átláthatóság teljesülése. Az alapvetô képességek fontos jellemzője, hogy általuk olyan termékek és szolgáltatások hozhatók létre, amelyek a versenytársaknál nagyobb értéket nyújtanak a fogyasztóknak (Prahalad - Hamel, 1990).

A szakirodalomban ma fellelhető legteljesebb meghatározást adja a Versenyképesség Kutató Központ több éven keresztül finomított definíciója (Chikán Czakó, 2009: p. 78.), mely szerint a vállalatok versenyképessége abban áll, hogy a társadalmi normák betartásával úgy kínálnak termékeket és szolgáltatásokat a fogyasztóknak, hogy azok hajlandók legyenek ezekért a versenytársakénál nagyobb jövedelmezôséget bizto- 
sító árat kifizetni. Ennek feltétele, hogy a vállalatok oly módon legyenek képesek alkalmazkodni a külsố és belsố változásokhoz, hogy a piaci versenykritériumokat a versenytársaiknál kedvezóbben tudják teljesíteni. E definícióban szintén hangsúlyos a környezeti alkalmazkodás és a kettôs értékteremtés követelménye. A fogyasztói igények előrejelzése és alakítása, illetve a nyereséges múködés a vállalatok hosszú távú fennmaradásának záloga (Chikán, 2003a, 2003b; Yuan - Wu, 2008). Tanulmányom témájához leginkább e megfogalmazás kapcsolható, hiszen saját megközelítésemben a vállalati versenyképesség eléréséhez elengedhetetlen a fogyasztói érték biztosítása. A fogyasztói érték létrehozásához elsố lépésként arra van szükség, hogy a vállalat értelmezni tudja a fogyasztói érték fogalmát, azaz azonosítani tudja fogyasztóinak legfontosabb értékdimenzióit, a teljesítmény fogyasztó által kritikusnak, fontosnak tartott jellemzóit. Ezek az értékdimenziók mutatják meg, hogy mivel tud a vállalkozás termékeivel/szolgáltatásaival fogyasztóinak értéket teremteni, és ily módon hozzájárulni saját vállalkozása sikeréhez, hosszú távú jövedelmezőségéhez is.

\section{Az értékteremtés tartalma}

Értékteremtés alatt olyan folyamatot értünk, melynek során a vállalat erôforrásainak fogyasztói értékké konvertálása megvalósul (Chikán, 2003a). Az előzőekben már taglalt kettôs értékteremtés (Chikán, 2003b) koncepcióban a fogyasztói igény kielégítése konceptuálisan a fogyasztói érték, a profitszerzés a tulajdonosi érték növelésével függ össze. A vállalat a fogyasztó számára hasznosságot jelentő terméket vagy szolgáltatást kínál, és amennyiben ez a hasznosság a fogyasztónak nagyobb értéket jelent, mint az érte fizetendó piaci ár nagysága, úgy a vállalatnak sikerült a fogyasztó számára fogyasztói értéket növelni. Kínálati oldalról tekintve a tranzakciót, azt kell figyelembe venni, hogy a termékértékesítésért vagy szolgáltatásnyújtásért kért piaci ár mennyiben képes az előállítás költségeit meghaladni, azaz képes-e a vállalat nyereséget elérni, és ezzel a tulajdonosok értéknöveléséhez hozzájárulni.

\section{A fogyasztói igény és a vállalati siker kapcsolata}

A keresletoldali versenyképesség vizsgálata szempontjából számomra a kettôs értékteremtés fogyasztói oldala releváns. A fogyasztói igények kielégítését és a profit elérését hosszú távon megcélzó vállalati múködés meghatározza a vállalati folyamatok hatékony és eredményes menedzsmentjének módját. A folyamatorientált szemléletnek megfelelően a beszerzés-termelésértékesítés láncot a vevő́i kereslet és az arra vonatkozó várakozás hozza múködésbe. A keresleti információk a vállalatoknak a következó szempontokból lehetnek meghatározók:

- felesleges kapacitások elkerülése,

- értékesíthetőségre és bevételre vonatkozó megbízhatóbb előrejelzések kialakítása,

- termelés és szolgáltatásnyújtás mennyiségi, minôségi kialakítása és idôbeli ütemezése,

- költségoptimalizálás.

Mindez összességében azt jelenti, hogy a sikeres vállalati múködés egyik vezérfonala a feltárt vevơi igény kielégítése. Így a vállalat versenyképességét döntô mértékben meghatározza, hogy képes-e tartósan vevốinek értéket teremteni (Chikán - Demeter, 2004: p. 75-76.).

Gallarza - Gill (2008) tanulmányukban szintén hangsúlyozzák, hogy a vevôknek nyújtott érték vizsgálata, egyrészt annak a menedzsment számára fontos stratégiai vonatkozásai miatt, másrészt a fogyasztóimagatartás-vizsgálatokban is releváns és meghatározó. A fogyasztói érték vizsgálatára, mint a hosszú távú üzleti teljesítmény (Oh, 2000), illetve az ismételt vásárlás (Jayanti - Ghosh, 1996) egyik fő indikátorára, napjainkban az akadémiai világ és a szakmai kutatások is növekvő figyelmet fordítanak.

\section{A fogyasztói érték fogalma és összetevói}

A fogyasztói/vevőiérték-kutatások sokszor abba a nehézségbe ütköznek, hogy az érték absztrakt volta és többféle jelentéstartalma, érzékelése miatt annak pontos meghatározása nem lehetséges (Zeithaml, 1988; Rao - Monroe, 1989; Dodds et al., 1991; Woodruff, 1997), ezért az elméletiérték-koncepció empirikus úton történő előzetes értékelése válik szükségessé (Lin et al., 2005).

A fogyasztóiérték koncepciója több megközelítés alapján is vizsgálható: termékközpontú értékesítési szemléletből kiindulva (Schmitt, 2003 in: Kozma, 2009) a Kotler-féle marketingkoncepción (vö. Kotler, 2003 in: Hou - Tang, 2008) és a közelmúltban elötérbe kerülő $\mathrm{CRM}-\mathrm{en}^{3}$ keresztuil a fogyasztóiélménymenedzsmentig (Schultz, 2003 in: Kozma, 2009). Ezen újabb értelmezések szerint a fogyasztói érték nagyrészt szubjektív (Hofmeister et al., 2003), azaz a fogyasztó személyes véleményét tükrözi arról, hogy a kapott termék és szolgáltatás mennyiben felel meg elvárásainak (Parasuraman et al., 1985), és annak érdekében, hogy ezt a vállalkozások megértsék és beépíthessék piaci stratégiájukba, nagy kihívásokkal kell szembenézniük.

Fogyasztói érték Chikán - Demeter (2004) alapján - akkor képződik, ha a fogyasztó adott tranzakcióból származó haszna meghaladja a kapott termék és szolgáltatáscsomag tulajdonlásának teljes költségét. 
Az értéknek e szubjektív megfogalmazása igen átfogó, melyet a vevóiérték-dimenziók (value dimensions) fogalmán keresztül bonthatunk ki (Gelei, 2006). Az értékdimenziók elemeire bontják a vevôi értéket, azt mutatják meg, hogy a kapott termék-, szolgáltatáscsomagnak melyek azok a fontosabb összetevői, dimenziói, amelyek jelentôs mértékben hozzájárulnak a vevői érték növekedéséhez (Walters, 2002 in: Gelei, 2006: p. a megszerzéséért adott ,áldozat” (pl. pénzmennyiség) közötti különbséget értékeli (1. táblázat).

Más szerzók a fogyasztói értéket többdimenziós észlelt fogyasztói értékként sokszor „komplexnek” (Lapierre, 2000), „többtényezősnek” (Babin et al., 1994), ,dinamikusnak” (Parasuraman - Grewal, 2000; Woodruff, 1997) vagy „szubjektívnek” (Zeithaml, 1988) definiálják (2. táblázat).

Válogatott egydimenziós fogyasztóiérték-értelmezések

\begin{tabular}{|l|l|}
\hline \multicolumn{1}{|c|}{ Kutatás } & \multicolumn{1}{c|}{ Értékkoncepció } \\
\hline Zeithaml (1988) & fogyasztóhasznosság értékelése a termékért/szolgáltatásért adott és kapott érték között \\
\hline Dodds et al. (1991) & észlelet minóség és áldozat közötti különbség \\
\hline Fornell et al. (1996) & fizetett ár és relatív minóség közötti különbség \\
\hline Oliver (1999) & pozitív funkció (kapott termék) és negatív funkció (áldozat) közötti különbség \\
\hline Morrison (1989)in: Murphy et al. (2000) & az egyén személyes költség-haszon elemzése \\
\hline Stevens (1992) & érték a pénzért koncepció: az ár, a minőség és mennyiség közötti kapcsolat \\
\hline Chang - Wildt (1994) in: Murphy et al. (2000) & a termék észlelt minóségének és az ahhoz kapcsolódó árnak a kombinációja \\
\hline
\end{tabular}

Forrás: Gallarza - Gil (2008: p. 6.)

A többdimenziós fogyasztóiérték-kutatások irányai

\begin{tabular}{|c|c|}
\hline Kutatási irányok & Kutatási fókusz \\
\hline $\begin{array}{l}\text { Cél-érték elmélet: } \\
\text { Vevôiérték-hierarchia }\end{array}$ & fogyasztói élmény (fogyasztási célok, tulajdonságok, következmények) \\
\hline Haszonelvú és hedonikus érték & $\begin{array}{l}\text { vásárlási élmény: 1. funkcionalizmus, racionalitás, eszközelvúség, feladatorientált, } \\
\text { 2. szórakozás- és érzelem-központúság, élményszerúség, }\end{array}$ \\
\hline Értékelmélet & $\begin{array}{l}\text { külső érték (hasznosságalapú fogyasztás), belső érték (érzelemalapú fogyasztás), rendszer } \\
\text { szemléletú érték (külsô és belsô érték közötti racionális kapcsolat) }\end{array}$ \\
\hline Fogyasztási érték elmélete & sokféle fogyasztási döntés lehetséges: pl. funkcionális, társadalmi, érzelmi, episztemikus, feltételes \\
\hline $\begin{array}{l}\text { Holbrook-félefogyasztóiérték- } \\
\text { tipológia }\end{array}$ & $\begin{array}{l}\text { „,interaktív, relatív, fogyasztói preferencián alapuló élmény”; } \\
8 \text { megkülönböztetett értéktípus (eredmény, kiválóság, státus, megbecsülés, szórakozás, etika, } \\
\text { esztétika, spiritualitás) } 3 \text { aspektusban (külsô vagy belsô, önmagára vagy másra irányuló, aktív } \\
\text { vagy reaktív) }\end{array}$ \\
\hline
\end{tabular}

Forrás: Sánchez-Fernández - Iniesta-Bonillo (2007) alapján

12.). A tevékenységmenedzsment szakirodalma gyakorlatilag ezzel a meghatározással azonosan használja a versenyelónyforrások fogalmát (Chikán - Demeter, 2004: p. 25.), s többnyire konkrétan felsorolja azokat a legfontosabb tényezőket, amelyek révén a vevői érték megragadható, illetve növelhetô, mindezek pedig az ár, minóség, rugalmasság, megbízhatóság és a központi termékhez kapcsolódó szolgáltatások.

Összességében a szakirodalom a fogyasztói értéket egydimenziós és többdimenziós értelemben is definiálja. A fogyasztói értéket egy dimenzió mentén megfogalmazó kutatók a tranzakciós értékre helyezik a hangsúlyt, ahol a fogyasztó a kapott termék/szolgáltatás és
A téma összefoglalásaként megállapítható, hogy a kétféle típusú fogyasztóiérték-értelmezés az alábbiakban tér el egymástól (3. táblázat).

A fogyasztói érték szakirodalmi áttekintése után levonható az a következtetés, hogy Holbrook tipológiája a legszélesebb körú, az érték gazdasági, társadalmi, hedonikus és altruista motívumait is egyaránt tartalmazza. Meglátásom szerint e felfogás elterjedésének nagy jelentősége lehet például a turizmusmenedzsmentben, egyrészt azért, mert a szerző az értéket nemcsak a vásárlási döntés előzményeként, hanem a fogyasztásból származó élmény eredményeként is értelmezi. Másrészt azért, mert ez esetben a standardizált szolgáltatások helyett inkább a turisták (fogyasztók) és turisztikai vállalkozások (szolgáltatók) kapcsolata, a

\section{VEZETÉSTUDOMÁNY}


fogyasztó számára pedig a személyes megtapasztalás élménye válhat meghatározóvá.

A fentiek értelmében egyre inkább a fogyasztó szubjektív észlelése, tapasztalata meghatározó a vásárolt termék, szolgáltatás végső értékelésekor. A fogyasztói elégedettségben fontos szerepet töltenek be az elôzetes várakozások, és ezekhez képest az észlelés. Az a vevő, akinek várakozásait meghaladja a vásárolt termék, illetve szolgáltatás hasznossága, hajlamos lojálisan viselkedni a vállalkozással, míg az, amelyik csalódott, könnyen elcsábítható. Sokszor azonban az elégedettség sem elégséges a tartós vevókapcsolathoz, ezenkívül a várakozásokon felül kapott érték hangsúlyosabb lehet (Chikán - Demeter, 2004).

Következtetésként megállapítható, hogy az eddigi értekezésekben a fogyasztóiérték-kutatások három területe jelent meg: 1. a termékválasztást és vásárlási szándékot, újravásárlást ösztönző értékek kutatása, 2. a minőség-érték-elégedettség-lojalitás összefüggések vizsgálata, 3 . a gazdasági-pszichológiai, azaz kognitívaffektív fogyasztóiérték-dimenziók kapcsolata.

A fogyasztóiérték-dimenziók feltárásához releváns megközelítés a multidimenzionalitás vizsgálata. A fogyasztói érték összetevôii között

- egyrészt megjelenhetnek a racionális (kognitív) döntésból adódó és funkcionalitásra összpontosító dimenziók (pl. az egyes szolgáltatáselemek ára és minősége),

- másrészt a fogyasztó termékkel kapcsolatos megítélésére ható affektív dimenziók (pl. a hangulat, érzések, kapcsolatok, élmények).

$A z$ élmény-értékdimenzió tágabb értelemben is értelmezhetố, elöfordulhat, hogy az affektív dimenziók összességét magában foglalja. De Yuan - Wu (2008) felfogásának további vizsgálatát is fontosnak érzem, mely szerint akár a teljes fogyasztói értékitélet alapulhat magán a komplex élményen. Kérdésként merülhet fel, hogy teljes mértékben megfeleltethetó-e egymásnak a fogyasztói érték és az élményérték?

\section{Fogyasztói érték az élmény kontextusában}

Az utóbbi években egyre nagyobb érdeklódés tapasztalható az élménykoncepció iránt, melynek oka lehet, hogy az élmények és intellektuális kihívások utáni vágy összefonódik a fogyasztói magatartás eltolódásával a materiális értékek felól az etikai és intellektuális értékek irányába. Olyan értékekról van szó, mint a szépség, az egészség, a barátság, az önmegvalósítás, a tolerancia, a környezettudatosság stb. Egyfajta reakció ez a fogyasztói társadalom túlzottan materialista orientációjára. A kemény materiális tényezók helyett az „új gazdaságban” az intellektuális készségek és képességek a fő értékteremtő́k gazdasági értelemben. A posztmaterialista értékek előtérbe kerüléséhez azonban magas színvonalú anyagi fogyasztás is szükséges, hiszen ezen értékekre egész iparágak épülnek rá: a bioélelmiszer-gyártóktól, a sportszergyártókon keresztül, az egzotikus túrákat szervezố utazási irodákig. A felkínált új termékek és szolgáltatások sokasága, a gyors választás és a fogyasztás dematerializálódása egyaránt abba az irányba haladnak, hogy a fogyasztó egyre kiszámíthatatlanabb, preferenciája egyre összetettebb lesz (Szabó - Hámori, 2006).

Az élmény kategóriájának értelmezése sokszínú. A humanisztikus pszichológia (vö. Maslow, 1972; Csíkszentmihályi, 1990), a szociológia (vö. Éber, 2008) mellett a marketing- és menedzsmentirodalomban is egyre elterjedtebb fogalom. A fogyasztói élmény elsố említése az 1980-as évek elejére tehetô, amikor Holbrook és Hirschman (1982) a racionális döntéseken alapuló fogyasztói magatartás felfogásának fő-

\section{A fogyasztóiérték-megközelítések összehasonlítása}

\begin{tabular}{|c|c|}
\hline \multicolumn{1}{|c|}{ Egydimenziós fogyasztói érték } & Többdimenziós fogyasztói érték \\
\hline Alapja: gazdálkodástudomány, kognitív pszichológia & Alapja: fogyasztóimagatartás-elmélete \\
\hline haszonelvú és gazdasági koncepció & magatartásp-szichológia \\
\hline kognitív megközelítés & kognitív-affektív megközelítés \\
\hline egyszerúség & komplexitás \\
\hline fókusz: hogyan értékeljünk & fókusz: hogyan növelhetô a fogyasztói érték \\
\hline konszenzushiány az értékelózményekben & konszenzushiány az értékkomponensek tekintetében \\
\hline tisztázatlan kapcsolatok az értékelőzmények között & tisztázatlan kapcsolatok az értékkomponensekben \\
\hline az érték közvetlen módon megfigyelhető & az érték csak közvetve, a komponensein keresztül figyelhető meg \\
\hline gyakori szakirodalmi megjelenés & ritka szakirodalmi megjelenés \\
\hline
\end{tabular}

Forrás: Sánchez-Fernández - Iniesta-Bonillo (2007: p. 442.) 
1. ábra zói az élményeknek. A szerzôk

Az élmény négy területe

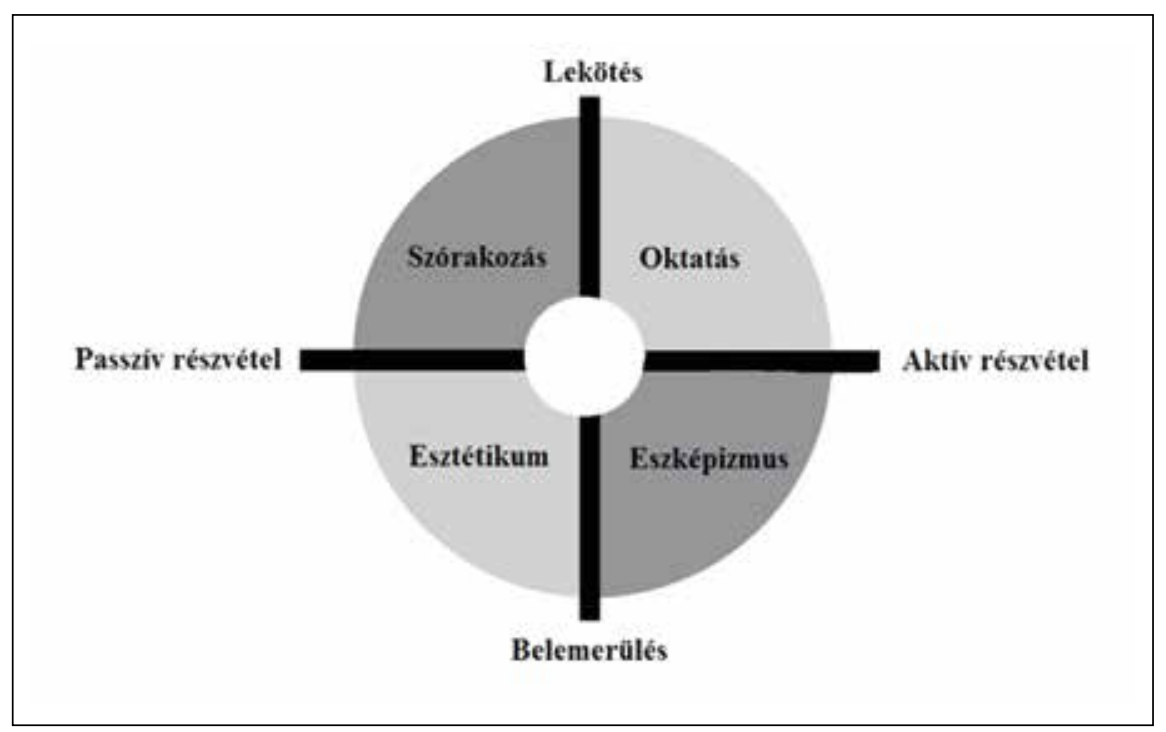

Forrás: Pine - Gilmore (1998: p. 102.)

árama mellett az élmény aspektusának figyelembevételére is felhívta a figyelmet. Pine - Gilmore (1998) úttöróként foglalkozott az élménygazdaság-koncepcióval. Elsốként a gazdasági érték fejlődését vizsgálták, mely szerint a piacon legalacsonyabb áron a tömegcikkeket találjuk, majd az ár növekedésével haladunk a termékek előállításán és a szolgáltatások nyújtásán át a legmagasabb árú prémiumélmény kialakításáig. Ez azonban nem azt jelenti, hogy egy vállalkozás a különböző szolgáltatásaihoz „csomagolt” élményekkel igazi élményt tud nyújtani. Maga az élménynyújtás egy, a szolgáltatást követô külön állomás. Meglátásuk szerint az élmények legfontosabb tulajdonsága, hogy emlékezetesek. Emellett azonban kulcsfontosságú jellemzőjük, hogy személyesek és a legmeghatározóbb értékjelzôk.

A XX. század utolsó éveiben az élmények „eladása" leginkább az amerikai színházakban és tematikus parkokban valósult meg. Ezek a mai napig nagy népszerúségnek örvendenek nemcsak az Egyesült Államokban, de a világ számos más országában is. Azonban rengeteg más olyan vállalkozás létezik, amelyek a szolgáltatások jobb, pontosabb kivitelezésével, vagy valamilyen „extra” nyújtásával próbálják a fogyasztók élményeit gyarapítani. Pine - Gilmore (1998) azt is hangsúlyozza, hogy az élmények sok apró karakterisztikával rendelkezhetnek, melyeknek mind a lehetô legjobban kell teljesülniük és harmonizálniuk egymással, hogy valós fogyasztói élményrôl beszélhessünk. A kitúnő design, marketing és szolgáltatás, a leleményesség és a megújuló készség mind kritikus jellem- felfogásában az élmény megragadhatóságának egyik dimenziója a fogyasztói részvétel foka, mely lehet passzív vagy aktív. A másik dimenziót a (környezeti) kapcsolat jelenti, vagyis maga a vevố és az esemény vagy tevékenység közti összeköttetés (figyelemlekötés vagy teljes belemerülés, átélés) (1. ábra).

Az említett dimenziók szerint négy széles kategóriába sorolhatjuk az élményeket: szórakozás, oktatás, eszképizmus, esztétikum. Legteljesebb élményt a négy terület együttese jelenthet. Szerzók (i. m.) a területek megnevezése mellett az élmény „megrendezésére” is javaslatot tesznek: tematizálás, egyediség pozitívuma, negatív elemek kiiktatása (pl. túlzások kerülése), emlékezetessé tétel (pl. szuvenír), az élmény mind az öt érzékszervvel történő megtapasztalásának lehetôsége.

Korunk gazdaságában keresleti oldalon a fogyasztói magatartás meghatározó eleme a fogyasztói döntés révén megszerzett élmény, a kínálati oldalon pedig az egyetlen jelentős versenyelőny abból származik, hogy egy vállalat milyen intenzitású élményt képes terméke vagy szolgáltatása megvásárlójának és elfogyasztójának nyújtani. Ily módon az élmény,mint termékösszetevố jelenik meg a piacon (Michalkó - Rátz, 2005).

Puczkó (2009) szerint a kreatív ipar (mint kínálat) és az élménygazdaság (mint kereslet) megjelenése visszavezethetô arra, hogy a fogyasztók életstílusa az intenzív, magas minôségú és többdimenziós élményszerzés részévé vált. A szabadidő eltöltéséból származó élmények típusa például megerôsíti a fogyasztót életstílusának jellemzóiben, mint:

- az aktív, részvételre épülő életvitel,

- kultúrán alapuló szabadidőtöltés,

- olyan környezet létrehozása, melyben nehéz megvonni a határt fogyasztó és szolgáltató között,

- stimuláció iránti igény erôs jelenlétén, vagy a virtuálison túli érdeklődésen alapuló fogyasztás.

Elmondhatjuk tehát, hogy az élmény iránti vágy már túlmutat a vásárláson, az élménygazdaság és élménytársadalom már nem szokatlan, sốt Puczkó (2009) tanulmányában hangsúlyozza, hogy az újszerúséget napjainkban az autentikus fogyasztás és „autentikus gazdaság" megjelenése képviseli. 
Az új körülmények között élő szabadidős fogyasztó jellemzője, hogy

- szeretne kitörni a lakás és a munka környezetéból,

- az otthoni élményeknél „fantasztikusabb” élményeket keres,

- kedveli a kikapcsolódást, szórakozást és az interaktív élményt

- tisztában van a „valós” és „mesterséges” élmény létezésével, de sokszor nem tesz különbséget,

- viszonylag fiatal (15-45 év közötti), és magas diszkrecionális jövedelemmel rendelkezik,

- individualista és független,

- élvezi a luxust, komfortot, biztonságot,

- kontrollált izgalmat keres,

- tudatos fogyasztó,

- rövid koncentrálóképesség és hajlandóság jellemzi,

- érdekli az új technológia és média,

- várakozásait az úgynevezett „3S-modell” írja le:

- surprise (meglepetés) - a fogyasztásban a meglepetés szerepe meghatározó, anélkül nincs élmény,

- sacrifice (áldozat) - az elvárt és az észlelt szolgáltatás kapcsolata az élmény és az érte hozandó áldozat viszonyán múlik,

- satisfaction (kielégítés) - optimális helyzetben a vágyott élmények, eredmények és a még elfogadhatónak tartott szintû́ kielégítések összehangolása kulcsfontosságú (i.m.: 26).

Számos kutatás (Uriely, 2005; Page - Connell, 2009; Carbone - Haeckel, 1994) eredménye bizonyítja, hogy a fogyasztói élmények összetevőjét alkothatja a vevố és szolgáltató (esetleg harmadik fél) között létrejövő interakció, az újdonság, különbözô viselkedést befolyásoló tényezók, a fogyasztó bekapcsolódása a szolgáltatás- és élménynyújtás folyamatába, valamint a vásárlás és fogyasztás emlékezetessége.

Korunk fogyasztói - különösen a turizmusban - már nem csupán terméket vagy szolgáltatást szeretnének megvásárolni, hanem komplex élményt, élményláncolatot. A vevốk szerepe és egyben szolgáltatásba történő bevonása is megnövekedett.

A jelenség Heinonen és szerzőtársai (2010) kutatásaiban a szolgáltatásnyújtás új, vevődomináns logikáját (Customer Dominant Logic) vezeti be, melyben a fogyasztói aktivitások, folyamatok, gyakorlatok, szellemi és érzelmi élmények, illetve tevékenységek határozzák meg a fogyasztói értéket. E nézet természetesen nem vonja kétségbe a szolgáltatói szerep fontosságát sem, csupán a fogyasztók és az óket körülölelő világ kapcsolatára nagyobb hangsúlyt fektet. A szerzók továbblépnek a termékek és szolgáltatások használati(value-in-use), birtokbavételi- (value-in-possession) és csereérték- (value-in-exchange) koncepcióján, és helyettük a sokkal átfogóbb, bár kevésbé bevezetett életérték (value-in-life) vagy élményérték (valu-inexperience) értelmezést preferálják (Turnbull, 2009). Meyer - Schwager (2007) értelmezése szerint a kapott élmény meghatározza azt is, hogy milyen közvetlen vagy közvetett kapcsolatot ápol a fogyasztó a vállalattal.

Az élményérték esetében is meghatározható annak külsó és belsố aspektusa (Babin et al., 1994; Mano Oliver, 1993). Általánosságban elmondható, hogy a külső értékészlelések a feladat elvégzéséből, míg a belső értékészlelések az élmények vidám és szórakoztató mivoltából adódnak (Babin et al., 1994; Holbrook, 1999). Mathwick és társai (2001) az előzőekben ismertetett, Holbrook által kialakított értéktipológiákat némileg egyszerúsítették, és olyan értékmérési skálát ajánlottak, mely a külső/belsố, illetve aktív/passzív dimenziók mentén a szolgáltatás kiválóságát, a fogyasztó számára jelentkezó megtérülést, az esztétikumot és a szórakozást tartalmazza.

Otto - Ritchie (1996) ezzel szemben a turisztikai szolgáltatásélmény mérésére a hedonizmust, a lelki nyugalmat, a részvételt (interakciót) és a megismerés dimenzióját emelte ki, melyek értelmezésemben tartalmazzák az általános fogyasztói érték kognitív és affektív dimenzióit, ily módon az érték- és élménykategóriák átfedését.

Gentile és szerzőtársai (2007) bôvebb meghatározásban, de hasonló tartalommal kiváló összefoglalóját adják azon élménykomponenseknek, melyek hozzájárulnak a fogyasztói érték növeléséhez:

- érzékelések: érzékszerveinkre, látásra, hallásra, tapintásra, ízlelésre és érintésre ható tényezók által kialakított fogyasztói élmény,

- érzelmek: a fogyasztó hangulata, érzései és érzelmei befolyásolják élményének értékelését,

- megértés: a fogyasztó termékról, szolgáltatásról és élményrốl alkotott véleményét meghatározza, mennyire érti meg és ismerte meg azt, a megértés hatással lehet a jövő́beli vásárlásokra is,

- gyakorlatiasság: a fogyasztói élmény az aktivitásból és részvételból származik,

- életstílus: az élmények az értékek és hiedelmek elfogadásából adódnak,

- kapcsolatok: az élmények a fogyasztón és az ôt körülvevő környezet társasági kapcsolatain alapulnak. 
Az értékszemlélet az élményvizsgálatokhoz olyan kutatási irányokat és megfogalmazásokat kapcsol, mint szolgáltatásélmény, fogyasztói élmény, vevői élmény, fogyasztási élmény, vásárlási élmény stb. (Carú - Cova, 2003; Harris et al., 2003; Gentile et al., 2007). Az értelmezések megegyeznek abban, hogy az élményt a szolgáltató rendezi, és a fogyasztó számára a személyes megtapasztalás alapján jelent értéket. Meyer - Schwager (2007) szerint a fogyasztói élmény a szolgáltató és a vevő között kialakult kapcsolat belsó és szubjektív értékelése. Prahalad és Ramaswamy (2004) meghatározása szerint az érték jelenleg a fogyasztók élményeiben összpontosul. Vargo és Lusch (2008) értelmezésében az érték mindig kedvezményezettjének egyedi és fenomenológiai észlelésétól függ, ezáltal az érték mindig sajátos, élményen és értelmen alapuló, illetve kontextusfüggó. Carú - Cova (2003) és Holbrook $(1999,2006)$ perspektívájában az élmények nemcsak kognitív és tervezett elemeket, hanem szubjektív, szeparálatlan érzéseket is tartalmaznak, míg az érték egy interaktív, relatív élmény. Ily módon az élmény a fogyasztó saját aktivitásából, magatartásából fakad, és hangulatától függ. Heinonen és szerzótársai (2010) hangsúlyozzák, hogy az élmény több, mint észlelések folyamata, sokkal inkább egy hosszú távú és kontextusfüggő kapcsolat.

\section{Konklúzió}

Következtetésképpen megállapíthatjuk, hogy mivel a komplex élmény tudományos értelmezése igen gazdag és szerteágazó, az egyes szerzók és kutatók élményelemekre vonatkozó meghatározásai szintén különbözőek. Ennek ellenére közös jellemvonásként említhetô, hogy: 1. a fogyasztó szolgáltatóval vagy annak termékével, más fogyasztókkal vagy a helyi lakosokkal való kapcsolatából származik, 2. személyes, 3. a fogyasztót holisztikus módon, racionális, érzelmi, érzéki, fizikai és spirituális tekintetben is befolyásolhatja.

\section{Lábjegyzet}

\footnotetext{
${ }^{1}$ Jelen cikk jelentős mértékben támaszkodik a következő értekezésre: Kulcsár Noémi (2012): Fogyasztóiérték-dimenziók a falusi turizmusban c. PhD-értekezés, BCE, Budapest (megjelenés alatt).

${ }^{2}$ A vevői érték megfogalmazása jelen tanulmányban azonosnak tekinthető a fogyasztóiérték-technológiájával, hiszen vizsgálódásom tárgya a fogyasztói (végfelhasználó) piacra összpontosul. Bizonyos hivatkozott irodalmak a vevói érték fogalmát használják - igaz ez fóként a tevékenységmenedzsment-irodalmakra -, ezért ilyen esetekben én is megtartom a vevői érték kifejezést.

${ }^{3}$ Customer Relationship Management, azaz vevóikapcsolatmenedzsment.
}

\section{Felhasznált irodalom}

Babin, B.J. - Darden, W.R. - Griffin, M. (1994): Work and/ or Fun: Measuring Hedonic and Utilitarian Shopping. Journal of Consumer Research, Vol. 20, No. 4: p. 644 656.

Barney J.B. (1996): Gaining and sustaining competitive advantage. Reading: Addison-Wesley

Botos, J. (1982): Nemzetközi versenyképesség és árforradalom. Budapest: Közgazdasági és Jogi Könyvkiadó (in: Némethné (2010)

Carbone, L.P. - Haeckel, S.H. (1994): Engineering customer experiences. Marketing Management, Vol. 3, No. 3: p. 8.

Carú, A. - Cova, B. (2003): Revisiting consumption experience. A more humble but complete view of the concept. Marketing Theory, Vol. 3, No. 2: p. 267-286.

Chikán A. - Czakó, E. (2009): Versenyben a világgal. Vállalataink versenyképessége az új évezred küszöbén. Budapest: Akadémiai Kiadó

Chikán A. - Demeter, K. (2004): Értékteremtő folyamatok menedzsmentje. Budapest: Aula Kiadó

Chikán A. (2003a): Vállalatgazdaságtan 3. bóvített kiadás. Budapest: Aula Kiadó: p. 92-116.

Chikán A. (2003b): A kettôs értékteremtés és a vállalat alapvető célja. Vezetéstudomány, 34. évf. 5. sz.: p. 10-12.

Chikán A. (2006): A vállalati versenyképesség mérése. Egy versenyképességi index és alkalmazása. Pénzügyi Szemle, 51. évf. 1. szám: p. 42-56.

Czakó E. (2000): Versenyképesség iparágak szintjén - a globalizáció tükrében. PhD-disszertáció. Budapest: BKÁE Vállalatgazdaságtan Tanszék

Csíkszentmihályi, M. (1990): The Flow. The psychology of optimal experience. New York: Harper and Row Publishers

Dodds, W. - Monroe, K.B. - Grewal, D. (1991): Effects of price, brand, and store information on buyers' product evaluations. Journal of Marketing Research, Vol. 28, August: p. 307-319.

Éber M. (2008): Túl az élménytársadalmon? - avagy az élménytársadalom másfél évtizede -. Szociológiai Szemle, 18. évf. 1. szám: p. 78-105. http://www.szociologia.hu/dynamic/0801eber.pdf (2011. 08.07.)

Findrik M. - Szilárd I. (2000): Nemzetközi versenyképesség. Képességek versenye. Budapest: Kossuth Kiadó, (in: Némethné (2010)

Fornell, C. et al. (1996): The American Customer Satisfaction Index: nature, purpose, and findings. Journal of Marketing, Vol. 60, No. 4.: p. 7-18.

Francis, A. (1989): The Concept of Competitiveness. in: Francis, A. - Tharakan, P.K.M. (1989): The Competitiveness of European Industry. London and New York: Routledge (in: Czakó (2000)

Francis, A. (1992): The Process of National Industrial Regeneration and Competitiveness. Strategic Management Journal, Vol. 13: p. 61-78. (in: Czakó (2000) 
Gallarza, M.G. - Gill, I. (2008): The concept of value and its dimensions: a tool for analysing tourism experiences. Tourism Review. Vol. 63, No. 3: p. 4-20.

Gelei A. (2006): Beszállítótípusok és azok alapvetô kompetenciái a hazai autóipari ellátási láncban. PhDértekezés. Budapest: Budapesti Corvinus Egyetem, Gazdálkodástani Doktori Iskola

Gentile, C. - Spiller, N. - Noci, G. (2007): How to Sustain the Customer Experience: An Overview of Experience Components. European Management Journal, Vol. 25, No. 5: p. 395-410.

Grant, R.M. (1991): The Resource-Based Theory of Competitive Advantage: Implication for Strategy Formulation. California Management Review, Vol. 33, No. 3: p. 114-135.

Gremler, D.D. (2004): The Critical Incident Technique in Service Research. Journal of Service Research, Vol. 7, No. 1: p. 65-89.

Harris, R. - Harris, K. - Baron, S. (2003): Theatrical service experiences. Dramatic script development with employees. International Journal of Service Industry Management, Vol. 14, No. 2: p. 184-199.

Heinonen, K. - Strandvik, T. - Mickelsson, K-J. (2010): A customer-dominant logic of service. Journal of Service Management, Vol. 21, No. 4.: p. 531-548.

Hofmeister T. Á. - Simon J. - Sajtos L. (2003): Fogyasztói elégedettség. Budapest: Alinea Kiadó

Holbrook, M.B. - Hirschman, E.C. (1982): The experiential aspects of consumption: Consumer fantasy, feelings and fun. Journal of Consumer Research, Vol. 9, No. 2: p. 132-140.

Holbrook, M.B. (ed.) (1999): Consumer Value: A Framework for Analysis and Research. London, New York: Routledge

Holbrook, M.B. (2006): Consumption experience, customer value, and subjective personal introspection: An illustrative photographic essay. Journal of Business Research, Vol. 59, No. 6: p. 714-725.

Hou, L. - Tang, X. (2008): Gap Model for Dual Customer Values. Tsinghua Science and Technology, Vol. 13, No. 3: p. 395-399. http://www.fvm.gov.hu/doc/upload/200711/ fatosz_elso_beszamolo.pdf (2011.07. 02.)

Jayanti, R.K. - Ghosh, A.K. (1996): Service value determination: an integrative perspective. Journalof Hospitality and Leisure marketing, Vol 3, No. 4: p. 5-25.

Kotler, P. (2003): Marketing Management. 11th Ed. New Jersey, USA: Pearson Prentice Hall (in: Hou - Tang (2008))

Kozma M. (2009): Értékteremtés Public-Private Partnership keretében - különös tekintettel a vállalkozó szempontjaira. PhD-értekezés. Budapest: Budapesti Corvinus Egyetem, Gazdálkodástani Doktori Iskola

Lapierre, J. (2000): Customer-Perceived Value in Industrial Contexts. The Journal of Business \& Industrial Marketing, Vol. 15, No. 2-3: p. 122-140.

Lengyel I. (2000): A regionális versenyképességról. Közgazdasági Szemle, XLVII. évf. december: p. 962-987.
Lin, C.H. - Sher, P.J. - Shih, H.-Y. (2005): Past progress and future directions in conceptualizing customer perceived value. International Journal of Service Industry Management, Vol. 16, No. 4: p. 318-336.

Majoros P. (1997): A külgazdasági teljesítmény, mint a nemzetközi versenyképesség közvetlen mércéje, illetve mint a technikai színvonal közvetett jelzôje. Európai Tükör, 7. szám

Mano, H. - Oliver, R.L. (1993): Assessing the Dimensionality and Structure of the Consumption Experience: Evaluation, Feeling and Satisfaction. Journal of Consumer Research, Vol. 20: p. 451-466.

Maslow, A. (1972): A Memorial Volume. Monterey, California: Brooks/Cole Publishing Company

Mathwick, C.-Malhotra, N. - Rigdon, E. (2001): Experiential value: conceptualization, measurement and application in the catalogue and Internet shopping environment. Journal of Retailing, Vol. 77: p. 39-56.

Meyer, C. - Schwager, A. (2007): Understanding customer experience. Harvard Business Review, Vol. 85, No. 2: p. 116-126.

Michalkó G. - Rátz T. (2005): A kulturális turizmus élménygazdaságtani szempontjai. in: Enyedi Gy. - Keresztély K. (2005): A magyar városok kulturális gazdasága. Magyarország az ezredfordulón. Stratégiai tanulmányok a Magyar Tudományos Akadémián. Múhelytanulmány. Budapest: MTA Társadalomkutató Központ. http://www. sulinet.hu/oroksegtar/data/ipar_es_gazdasagtortenet/A_ magyar_varosok_kulturalis_gazgasaga/index.htm (2011. 08. 28.)

MTH (2005): Nemzeti Turizmusfejlesztési Stratégia 20052013. Magyar Turisztikai Hivatal Turizmus Bulletin, 9 évf. Különszám

Murphy, P.E. - Pritchard, M.P. - Smith, B. (2000): The destination product and its impact on traveller perceptions. Tourism Management, Vol. 21, No. 3: p. 43-52.

Némethné G. A. (2010): A kis- és középvállalatok versenyképessége - egy lehetséges elemzési keretrendszer. Közgazdasági Szemle, LVII. évf. február: p. 181-193.

NGM (2011): Turizmusfejlesztési stratégia. Szakmai vitairat. 2011. május. p. 51. http://www.turizmus.com/docs/ turizmusfejlesztesi_strategia.pdf (2011. 09.02.)

Oh, H. (2000): Diners' perceptions of quality, value and satisfaction. Cornell Hotel and Restaurant Administration Quarterly, Vol. 41 No. 3: p. 58-66.

Oliver, R.L. (1999): Value as excellence in the consumption experience. in: Holbrook, M.B.: Consumer Value: A Framework for Analysis and Research. London: Routledge p. 43-62.

Otto, J.E. - Ritchie, J.R. (1996): The service experience in tourism. Tourism Management, Vol. 17, No. 3: p. 165174.

Page, S.J. - Connell, J. (2006): Tourism: A Modern Synthesis. 3th ed. Hampshire, United Kingdom: Cengage Learning EMEA 
Parasuraman, A. - Grewal, D. (2000): The Impact of Technology on the Quality- Value-Loyalty Chain: A Research Agenda. Journal of the Academy of Marketing Science, Vol. 28, No. 1: p. 168-174.

Parasuraman, A. - Zeithaml, V.A. - Berry, L.L. (1985): SERVQUAL: A Conceptual Model of Service Quality and Its Implications for Future Research. Journal of Marketing, Vol. 49, Fall: p. 41-50.

Pine, B.J. - Gilmore, J.H. (1998): Welcome to the Experience Economy. Harvard Business Review, July-August: p. 97-105.

Porter, M.E. (1990): The Competitive Advantage of Nations. New York: The Free Press

Prahalad, C.K. - Ramaswamy, V. (2004): Co-creation Experiences: The next practice in value creation. Journal of Interactive Marketing, Vol. 18, No. 3: p. 5-14.

Pralahad, C.K. - Hamel, G. (1990): The core competence of the corporation. HBR, May-June: p. 79-91.

Puczkó L. (2009): A szabad munkától a munkás szabadságig - és vissza! Magyar Fogyasztó, No. 1: p. 24-26. www. magyarfogyaszto.hu/file/MFSZ_SZI.pdf (2011. 08. 27.)

Rao, R.A. - Monroe, K.B. (1989): The effect of price, brand name, and store name on buyers' perceptions of product quality: an integrative review. Journal of Marketing Research, Vol. 26, August: p. 351-357.

Sánchez-Fernández, R. - Iniesta-Bonillo, M.Á. (2007): The concept of perceived value: a systematic review of the research. Marketing Theory, Vol. 7, No. 4: p. 427-451.

Schmitt, B.H. (2003): Customer Experience Management - A revolutionary approach to connecting with your customers. New Jersey: John Wiley \& Sons. (in: Kozma, M. (2009)

Schultz, D.E. (2003): Evolving Marketing and Marketing Communication into the 21st Century. in: Iacobucci, D. - Calder, B.: Kellogg on Integrated Marketing. New Jersey: John Wiley \& Sons (in: Kozma, M. (2009)

Stevens, B. (1992): Research notes and communications: price value perceptions of travellers. Journal of Travel Research, Vol. 31. No. 2: p. 44-48.
Szabó K. - Hámori B. (2006): Információgazdaság. Digitális kapitalizmus vagy új gazdasági rendszer? Budapest: Akadémiai Kiadó

Szentes T. et al. (2005): Fejlődés - versenyképesség globalizáció. Budapest: Akadémiai Kiadó

Sziva,I.(2010):Turisztikaidesztinációk versenyképességének értelmezése és elemzése. PhD-értekezés. Budapest: Budapesti Corvinus Egyetem, Gazdálkodástani Doktori Iskola

Török, Á. (1996): A versenyképesség-elemzés egyes módszertani kérdései. Múhelytanulmány. Versenyben a világgal kutatási program. Budapest: BKE Vállalatgazdaságtan Tanszék (in: Czakó (2000)

Török Á. (2005): A versenyképesség értelmezései, különféle aspektusai és szintjei, meghatározó tényezői és mérésének módozatai (in: Szentes T. et. al. (2005)

Turnbull, J. (2009): Customer Value-in-Experience: Theoretical foundation and research agenda. ANZMAC. http://www.duplication.net.au/ANZMAC09/papers/ ANZMAC2009-282.pdf (2011. 08. 12.)

Uriely, N. (2005): The tourist experience - conceptual developments. Annals of Tourism Research, Vol. 32: p. 199-216.

Vargo, S. - Lusch, R. (2008): Service-Dominant Logic: Continuing the Evolution. Journal of the Academy of Marketing Science. Vol. 36: p. 1-10.

Walters, D. (2002): Operations strategy. New York: Palgrave - MacMillan (in: Gelei, A. (2006)

Woodruff, R.B. (1997): Customer Value: The Next Source for Competitive Advantage. Journal of the Academy of Marketing Science, Vol. 25, No. 2: p. 139-153.

Yuan, Y-H.E. - Wu, C.K. (2008): Relationships Among Experiential Marketing, Experiential Value, and Customer Satisfaction. Journal of Hospitality \& Tourism Research, Vol. 32, No. 3: p. 387-410.

Zeithaml, V.A. (1988): Consumer perceptions of price, quality, and value: a means-end model and synthesis of evidence. Journal of Marketing, Vol. 52, No. 3: p. 2-22.

\section{E S Z ÁM U N K S Z E R Z Ö I}

Dr. Fülöp Gyula, egyetemi tanár, Miskolci Egyetem; Hódiné Hernádi Bettina, egyetemi tanársegéd, Miskolci Egyetem; Dr. Jászberényi Melinda, PhD, egyetemi docens, Budapesti Corvinus Egyetem; Holczmann Anita, key account manager, Bare International; Dr. Kulcsár Noémi, PhD, fóiskolai docens, Budapesti Kommunikációs és Üzleti Főiskola; Dr. Kontor Enikő, egyetemi adjunktus, Debreceni Egyetem; Géring Zsuzsanna, tudományos munkatárs, Budapesti Gazdasági Fóiskola; Dr. Vörösmarty Gyöngyi, egyetemi docens, Budapesti Corvinus Egyetem; Kiss János, egyetemi adjunktus, Budapesti Corvinus Egyetem; Sándor Tímea, PhD-hallgató, Debreceni Egyetem 